\title{
Binding of hypoglycaemic sulphonylureas to an artificial phospholipid bilayer
}

\author{
M.Deleers and W.J. Malaisse \\ Laboratory of Experimental Medicine, Brussels University Medical School, Brussels, Belgium
}

\begin{abstract}
Summary. Hypoglycaemic sulphonylureas bind to multilamellar liposomes formed of egg yolk phosphatidylcholine. In this artificial model, both specific and non-specific components of the binding phenomenon can be characterized by the same criteria as those used in studies performed with natural membranes. The relative ability of distinct sulphonylureas to inhibit the binding of ${ }^{3} \mathrm{H}$-glibenclamide or ${ }^{3} \mathrm{H}$-gliquidone to the liposomes parallels their relative potency as insulin secreta-
\end{abstract}

gogues. It is proposed that the insertion of hypoglycaemic sulphonylureas into the phospholipid domain of the B cell membrane could represent a primary event in the mechanism by which these agents stimulate insulin release.

Key words: Liposomes, phospholipid, hypoglycaemic sulphonylurea, glibenclamide, gliquidone, gliclazide, tolbutamide, chlorpropamide.
Hypoglycaemic sulphonylureas stimulate insulin release, apparently by facilitating the inflow of $\mathrm{Ca}^{2+}$ into the pancreatic B cell $[1,2]$. Most authors favour the view that the stimulation of $\mathrm{Ca}^{2+}$ inflow is secondary to a decrease in $\mathrm{K}^{+}$conductance, leading to depolarization of the plasma membrane and gating of voltage-sensitive calcium channels [3-6]. The molecular mechanism responsible for the change in $\mathrm{K}^{+}$permeability is not known [7]. Radioisotopic studies of sulphonylurea uptake by isolated islets suggest that these hypoglycaemic agents are bound to the plasma membrane of pancreatic $B$ cells [8-10], which could be equipped with sulphonylurea receptors [11]. The cell boundary [12] could therefore represent the primary site of action of hypoglycaemic sulphonylureas.

The aim of the present study was to investigate how far the binding of sulphonylureas to natural membranes could be simulated in an artificial model of phospholipid bilayer.

\section{Materials and methods}

Egg yolk phosphatidylcholine was purchased from Sigma (St. Louis, Missouri, USA). ${ }^{3} \mathrm{H}$-glibenclamide $(31.1 \mathrm{Ci} / \mathrm{mmol})$ was kindly provided by M.H. Mertens (Hoechst Belgium, Brussels, Belgium), and ${ }^{3} \mathrm{H}$-gliquidone ( $4.8 \mathrm{Ci} / \mathrm{mmol}$ ) by $\mathrm{Dr} \mathrm{N}$. Kaubisch (Boehringer, Ingelheim, FRG) and Dr Rupprecht (Thomae, Biberach, FRG). Both sulphonylureas were tritiated in the cyclohexyl ring and their purity assessed by chromatographic analysis to be $>96 \%$. Unlabelled glibenclamide and tolbutamide were obtained from Hoechst, gliquidone from Thomae, gliclazide from Servier Benelux, Brussels, Belgium and chlorpropamide from Pfizer, Brussels, Belgium.

Multilamellar liposomes of egg yolk phosphatidylcholine were formed as described elsewhere [13] in a Tris- $\mathrm{HCl}$ buffer $(50 \mathrm{mmol} / 1$, $\mathrm{pH} 7.30$ ) yielding a final concentration of $2 \mathrm{mg} / \mathrm{ml}$. The sulphonylureas were added to this buffer from stock solutions prepared in a mixture of ethanol and $0.1 \mathrm{~N} \mathrm{NaOH}(1 / 1, \mathrm{v} / \mathrm{v})$, the final concentration of these solvents not exceeding $0.2 \%(\mathrm{v} / \mathrm{v})$. Aliquots $(0.25 \mathrm{ml})$ of the liposomal suspension were placed in polyethylene microcentrifuge tubes (Beckman, Palo Alto, California, USA), incubated for 5-60 $\min$ at $37^{\circ} \mathrm{C}$, and centrifuged for $30 \mathrm{~min}$ at $4{ }^{\circ} \mathrm{C}$ and $3,000 \mathrm{~g}$. The supernatant solution was then removed and the bottom of the tube containing the pellet of liposomes cut, placed in a counting vial containing $6 \mathrm{ml}$ of scintillation fluid (Aquasol-2; New England Nuclear, Boston, Massachusetts, USA), and eventually examined for its radioactive content.

The specific radioactivity of ${ }^{3} \mathrm{H}$-glibenclamide or ${ }^{3} \mathrm{H}$-gliquidone was kept unchanged in all experiments, except for measurement of the non-specific binding in which case unlabelled sulphonylurea was added at a final concentration of $0.1 \mathrm{mmol} / 1$. Such a non-specific binding was measured for each condition under study. Results are expressed as mean \pm SEM values together with the numbers of individual determinations (n).

\section{Results}

At a $20 \mathrm{nmol} / 1$ concentration of ${ }^{3} \mathrm{H}$-gliquidone, the apparent binding of the sulphonylurea to the liposomes reached an equilibrium value within $15 \mathrm{~min}$ of exposure to the drug (Figure 1). At the same concentration of the radioactive compound but in the presence of a much 
higher concentration of unlabelled gliquidone $(0.1$ $\mathrm{mmol} / \mathrm{l}$ ), the radioactivity associated with the liposomes also rapidly reached equilibrium. Further experiments were performed over $30 \mathrm{~min}$ incubation.

In experiments performed in the presence of a $10 \mathrm{nmol} / 1$ concentration of ${ }^{3} \mathrm{H}$-sulphonylurea and a $0.1 \mathrm{mmol} / 1$ concentration of the unlabelled drug, the total binding of glibenclamide and gliquidone averaged $13.3 \pm 0.7$ and $28.2 \pm 0.9 \mathrm{nmol} / \mathrm{mg}$ of phospholipid, respectively $(n=6-10)$. This corresponds to approximately $1.00 \pm 0.05$ and $2.12 \pm 0.07 \mathrm{~mol}$ sulphonylurea $/ 100$ mol phospholipid. If the binding of ${ }^{3} \mathrm{H}$-sulphonylurea at this high concentration of the unlabelled agent is as-

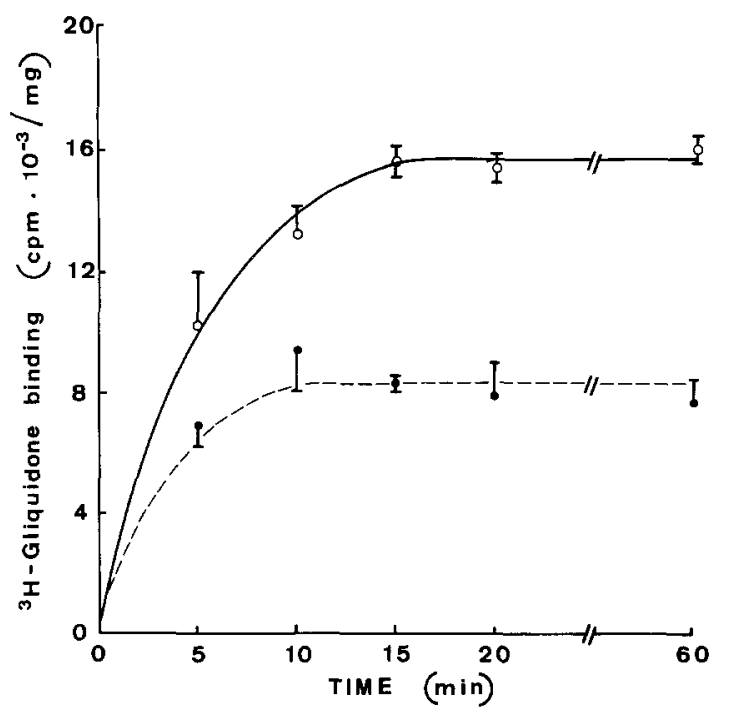

Fig. 1. Time course for the total $\left(\mathrm{O}_{-} \mathrm{O}\right)$ and non-specific (-... ) binding of ${ }^{3} \mathrm{H}$-gliquidone $(20 \mathrm{nmol} / \mathrm{l})$ to liposomes as measured in the absence and presence of unlabelled gliquidone $(0.1 \mathrm{mmol} / 1)$, respectively. Mean \pm SEM values refer to four individual determinations and are expressed as $\mathrm{cpm} \cdot 10^{-3} / \mathrm{mg}$ phospholipid. sumed to represent the non-specific binding, it should be substracted from other readings in order to characterize the specific binding of ${ }^{3} \mathrm{H}$-sulphonylurea. In a range of concentrations from 0.2 to $10.0-15.0 \mathrm{nmol} / 1$, such a specific binding was not quite proportional to the drug concentration (Fig. 2), the specific binding recorded at the highest concentration amounting to only $63 \%$ (glibenclamide) and $77 \%$ (gliquidone) of the theoretical values obtained by linear extrapolation of the data collected at the four lowest concentrations of sulphonylurea (i.e. between 0.2 and $2.0 \mathrm{nmol} / 1$ ).

Figure 3 illustrates the effect of increasing concentrations of unlabelled gliquidone and gliclazide upon the specific binding of ${ }^{3} \mathrm{H}$-glibenclamide $(10.0 \mathrm{nmol} / 1)$. Within the range of concentrations under investigation $(10.0 \mathrm{nmol} / 1$ to $0.1 \mathrm{mmol} / \mathrm{l})$, the binding of ${ }^{3} \mathrm{H}$-glibenclamide was much more severely inhibited by gliquidone than by gliclazide. Tolbutamide also slightly decreased ${ }^{3} \mathrm{H}$-glibenclamide binding $(p<0.01)$, whereas chlorpropamide failed to affect ${ }^{3} \mathrm{H}$-glibenclamide binding significantly ( $p>0.1$; data not shown).

The inhibition of ${ }^{3} \mathrm{H}$-gliquidone-specific binding by unlabelled sulphonylureas is illustrated in Figure 4. The three drugs tested, namely gliclazide, tolbutamide, and chlorpropamide, all caused significant inhibition. The slopes of the regression lines for the inhibitory effect were not vastly different from one another. However, the concentrations of sulphonylurea required to cause $50 \%$ inhibition of ${ }^{3} \mathrm{H}$-gliquidone-specific binding spanned a range of at least two orders of magnitude, averaging $0.6 \mu \mathrm{mol} / 1$ with gliclazide, $6.4 \mu \mathrm{mol} / 1$ with tolbutamide and $0.1 \mathrm{mmol} / 1$ with chlorpropamide.

\section{Discussion}

In this study we have investigated the binding of hypoglycaemic sulphonylureas to liposomes formed of egg
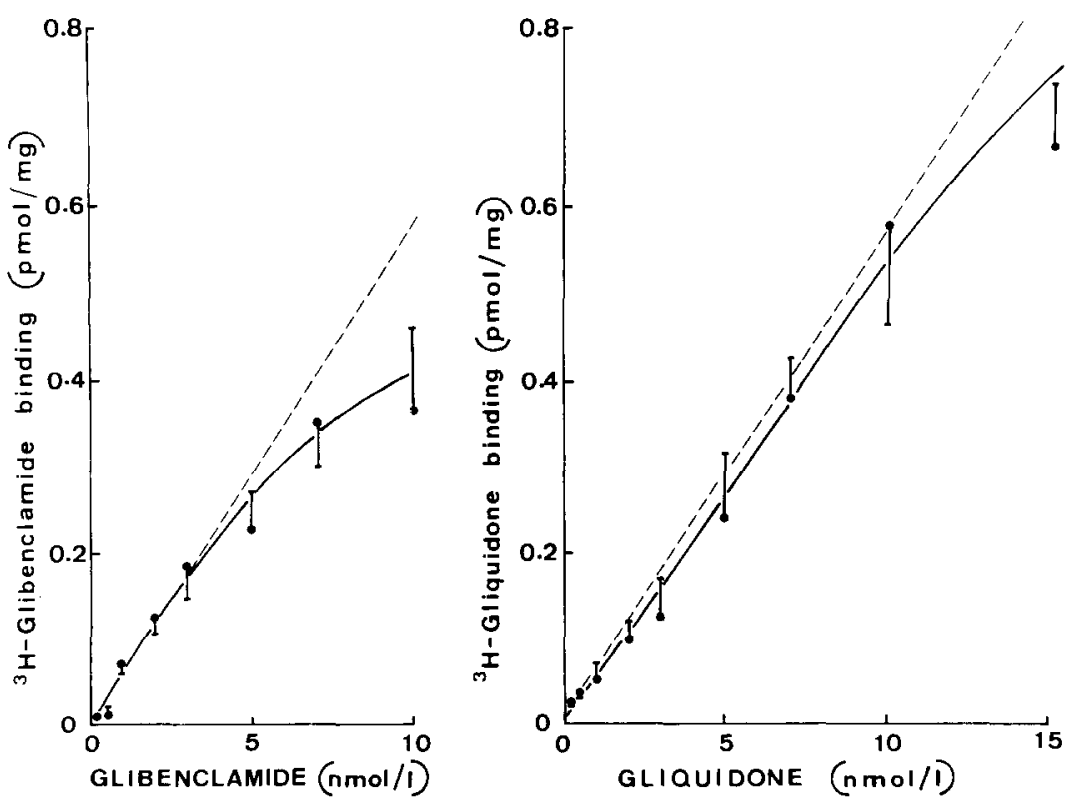

Fig. 2. Relationship between concentration and specific binding of ${ }^{3} \mathrm{H}$-glibenclamide and ${ }^{3} \mathrm{H}$-gliquidone to liposomes. Mean \pm SEM values refer to six to ten individual determinations and are expressed as pmol sulphonylurea bound $/ \mathrm{mg}$ phospholipid. The dotted lines illustrate relationships of proportionality with a slope derived from the data collected at the four lowest concentrations of sulphonylurea $(0.2-2.0 \mathrm{nmol} / \mathrm{l})$ 


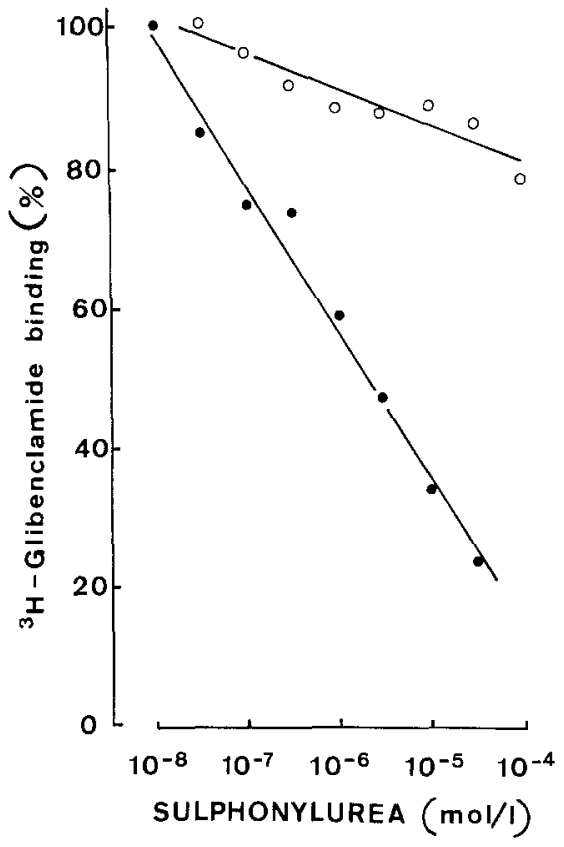

Fig. 3. Inhibition of the specific binding of ${ }^{3} \mathrm{H}$-glibenclamide $(10 \mathrm{nmol} / \mathrm{l})$ to liposomes by increasing concentrations of unlabelled gliquidone $(-O)$ ) or gliclazide $(\mathrm{O}-\mathrm{O})$. Each value refers to the point-moving mean derived from quintuplate measurements performed at each concentration of sulphonylurea. The SEM for individual measurements averaged $9 \%$.

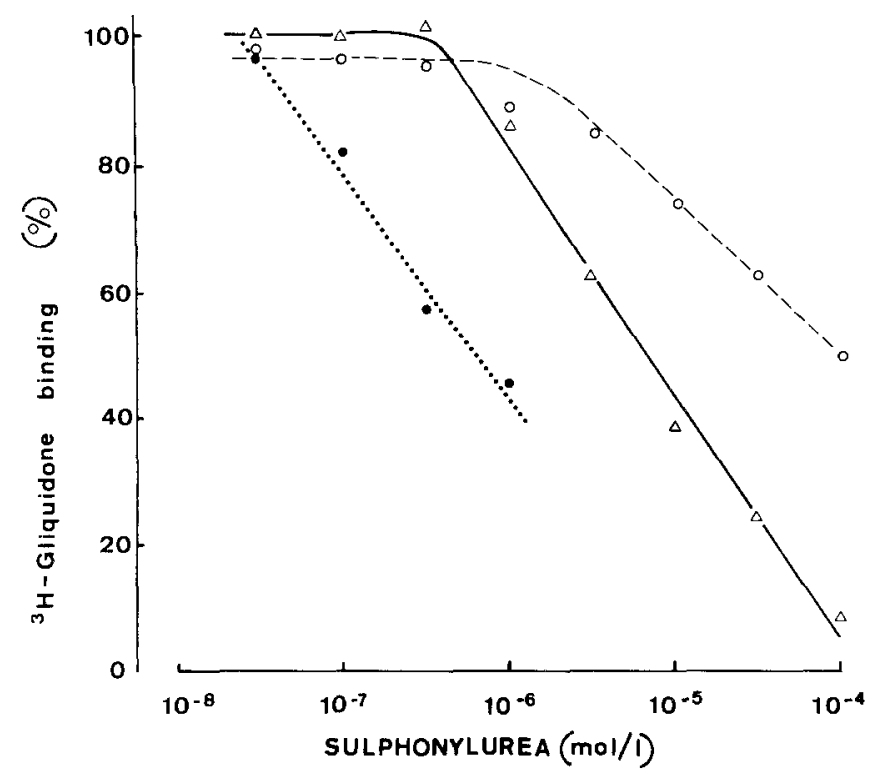

Fig.4. Inhibition of the specific binding of ${ }^{3} \mathrm{H}$-gliquidone $(10 \mathrm{nmol} / \mathrm{l})$ to liposomes by increasing concentrations of unlabelled gliclazide $\left(\bullet_{---}\right)$, tolbutamide $(\triangle \longrightarrow \Delta)$ and chlorpropamide $(\mathrm{O}---\mathrm{O})$. Same presentation as in Fig. 3. The SEM for individual measurement averaged $17 \%$.

yolk phosphatidylcholine. Our results refer to a binding phenomenon rather than penetration of the drug into the vesicular lumen. Indeed, at the concentration of phospholipid used here $(0.5 \mathrm{mg} / 250 \mu \mathrm{l})$, the intravesicular space of multilamellar liposomes does not exceed $1 \%$ of the volume of incubation medium [14], where- as the liposome-associated radioactivity represented $34 \%-64 \%$ of the total radioactivity present in each sample. Three major analogies can be found between the present results and those obtained with natural membranes.

First, in our system just as in brain membranes [11] or intact islets [15-17], the total binding of $\left[{ }^{3} \mathrm{H}\right]$ sulphonylurea increased progressively, albeit not proportionally, as the concentration of sulphonylurea was raised in a range between $0.2 \mathrm{nmol} / 1$ and $0.1 \mathrm{mmol} / 1$. At the latter concentration, the equilibrium value for total binding to intact islets averaged $0.15,0.67$ and $3.15 \mathrm{mmol} / \mathrm{kg}$ dry weight in the case of tolbutamide [15], glibornuride [16] and glibenclamide [17], respectively. If these values are representative of binding to the plasma membrane, as proposed by the Umeå group, they would correspond, in the case of glibenclamide, to a sulphonylurea/ phospholipid molar ratio close to unity. This estimation is based on the knowledge that, in pancreatic islets, the plasma membrane/dry weight ratio is close to $1700 \mathrm{~m}^{2} / \mathrm{kg}$ dry weight $[18,19]$ and that the content in phospholipids (averaged molecular weight taken as 750) of biological membranes is close to $1.4 \mathrm{mg} / \mathrm{m}^{2}[20$, 21]. However, if the hypoglycaemic sulphonylureas were located not only in the plasma membrane but also in the membrane of intracellular organelles - a view which cannot yet be ruled out - the glibenclamide/ phospholipid molar ratio could fall from 1.0 to a value as low as 0.02 , the total phospholipid content of islets averaging $230 \mathrm{mmol} / \mathrm{kg}$ protein [22]. In the present system and at the same initial concentration of sulphonylurea $(0.1 \mathrm{mmol} / \mathrm{l})$, the sulphonylurea/phospholipid ratio was close to $0.01-0.02$. The latter values could be somewhat underestimated. Indeed, if allowance is made for the fact that we are dealing with multilamellar liposomes (approximately 5-15 layers) [23], the true binding to the outer bilayer of phospholipids could be higher than the value calculated by reference to the total amount of phospholipid present in each sample. There appears, therefore, to be a fair agreement between data collected in living cells and our artificial model.

A second analogy between the artificial and biological systems consists in the fact that it is possible, in both models, to isolate a component of the binding phenomenon which can be operationally defined as specific binding. The saturation of this specific binding appeared to be reached at much lower concentrations of sulphonylurea in brain membranes $(1.0 \mathrm{nmol} / 1)$ than in liposomes. It could be disputed that our artificial membrane contains no specific receptors and hence the terms 'specific' and 'non-specific' binding were used here incorrectly. However, the aim of the present study was to test precisely whether artificial membranes devoid of specific receptor might behave phenomenologically in the same manner as natural membranes. Our experimental data demonstrate that, within limits, such is the case. A similar situation was recently observed for the binding of tumour-promoting phorbol esters to lipo- 
Table 1. Relative biological potency of hypoglycaemic sulphonylureas (and a sulphonamide)

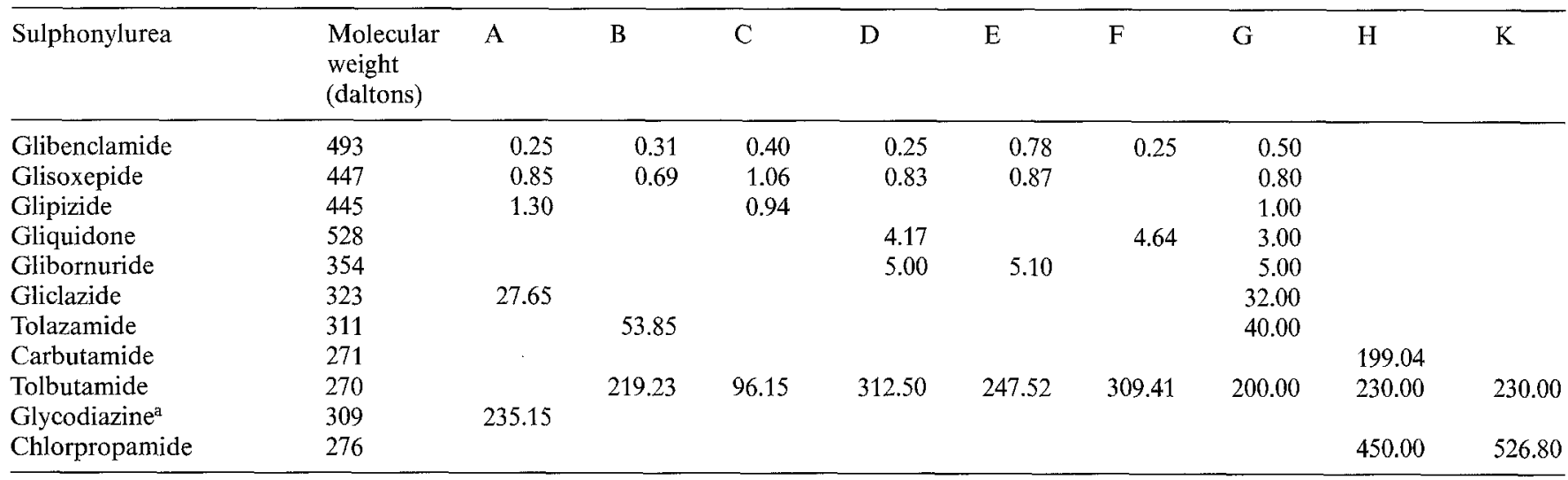

a Sulphonamide.

The relative biological potency of each drug was judged from (A) the dose-action relationship for insulin release by pieces of rat pancreatic tissue [26, 27]; (B) the dose-action relationship for the maximal fall in blood glucose concentration after oral administration to normal subjects [28]; (C) the dose-action relationship for the maximal decrease in blood glucose concentration after intravenous administration to normal conscious dogs [29]; (D) the doses causing a 30\% decrease in blood glucose concentration after intravenous administration to normal healthy volunteers [30, 31]; (E) the doses yielding comparable integrated glycaemic profiles after intravenous administration to normal subjects [32]; (F) the doses provoking comparable glycaemic decreases after oral or intravenous administration to normal subjects [33, 34]; (G) the minimal therapeutic doses [11, 35], chlorpropamide being excluded from this series because of its unusually long half-life; $(\mathrm{H})$ the increments in glucose fractional removal rate $(\mathrm{K}$ value) observed after intravenous administration of a low dose $(5 \mathrm{mg} / \mathrm{kg}$ body weight) of each drug to anaesthetized dogs [36, 37]; and (K) the decrease in blood glucose concentration observed $2 \mathrm{~h}$ after oral administration of a low dose $(10 \mathrm{mg} / \mathrm{kg}$ body weight) of sulphonylurea to monkeys [38]. In each column, the data are expressed relative to one another, according to the reference(s) cited. The absolute values in different columns were adjusted to provide comparable data for the same drug(s). Some agents, which are not cited elsewhere in this report, are listed in the Table because they were used to establish the correspondence between the different columns. All comparisons refer to the concentration or dosage required to achieve a given secretory or glycaemic response, results being expressed in weight units rather than molar units

somes and biological membranes, respectively [24]. It should be emphasized that the distinction between specific and non-specific binding in the present work neither implies nor rules out the existence of distinct modalities of interaction between sulphonylureas and phospholipids. The present data merely reflect a lack of proportionality between total binding and drug concentration. Further work is required both to characterize the modality or modalities of interaction (e.g. hydrophobic versus hydrophilic) between hypoglycaemic sulphonylureas and phospholipids and to distinguish, in biological membranes, between the insertion of these agents in the phospholipid domain and their possible binding to membrane-associated proteins.

A third and striking analogy was found in the ability of distinct sulphonylureas to inhibit the binding of a given drug. In the liposomes, the $\mathrm{K}_{\mathrm{i}}$ for inhibition of ${ }^{3} \mathrm{H}$ glibenclamide by gliquidone was close to $2.1 \mu \mathrm{mol} / 1$, whereas biologically less potent sulphonylureas (gliclazide, tolbutamide, chlorpropamide) tested at concentrations up to $0.1 \mathrm{mmol} / \mathrm{l}$ caused only modest to marginal decreases in ${ }^{3} \mathrm{H}$-glibenclamide-specific binding. The relative potency of gliclazide, tolbutamide and chlorpropamide in inhibiting ${ }^{3} \mathrm{H}$-gliquidone binding to liposomes paralleled their respective biological potency as insulin secretagogues (Table 1 ). The $\mathrm{K}_{\mathrm{i}}$ was close to $6.4 \mu \mathrm{mol} / 1$ with tolbutamide, which compares favourably with the values of $2.7 \mu \mathrm{mol} / 1$ reported by Kaubisch et al. in brain membranes [11]. Likewise, in intact islets from obesehyperglycaemic mice, the total binding of ${ }^{3} \mathrm{H}$-glibencla- mide is unaffected by tolbutamide [25], that of ${ }^{3} \mathrm{H}$-glibornuride reduced by glibenclamide $(-21 \%)$ but not by tolbutamide [16], and that of ${ }^{3} \mathrm{H}$-tolbutamide inhibited $(-34 \%)$ by glibenclamide [15], all experiments being carried out at a $20 \mu \mathrm{mol} / 1$ concentration of ${ }^{3} \mathrm{H}$-sulphonylurea and a $0.1 \mathrm{mmol} / 1$ concentration of the unlabelled potential inhibitor. Thus, whether in intact islets, brain membranes or liposomes, there was a close parallel between the relative biological potency of distinct sulphonylureas as insulin secretagogues and their relative ability to cause reciprocal inhibition of binding.

These analogies raise the idea that the insertion of hypoglycaemic sulphonylureas in the phospholipid domain of the $B$ cell membrane may represent the first step in the sequence of cytophysiological events leading to stimulation of insulin release by these agents. Hence, the ability of distinct sulphonylureas to penetrate into the phospholipid domain of cell membrane(s) could well represent one of the main factors conditioning their biological potency.

Acknowledgements. The authors are grateful to M. Mahy for technical assistance and C.Demesmaeker for secretarial help. This work was supported in part by grants from the Belgian Foundation for Scientific Research and Belgian Ministry of Scientific Policy.

\section{References}

1. Malaisse WJ, Mahy M, Brisson GR, Malaisse-Lagae F (1972) The stimulus-secretion coupling of glucose-induced insulin release. VIII. Combined effects of glucose and sulfonylureas. Eur J Clin Invest 2: 85-90 
2. Lebrun P, Malaisse WJ, Herchuelz A (1982) Modalities of gliclazide-induced $\mathrm{Ca}^{2+}$ influx into the pancreatic B cell. Diabetes 31: 1010-1075

3. Henquin JC (1980) Tolbutamide stimulation and inhibition of insulin release: studies of the underlying ionic mechanisms in isolated rat islets. Diabetologia 18: 151-160

4. Henquin JC, Meissner HP (1982) Opposite effects of tolbutamide and diazoxide on ${ }^{86} \mathrm{Rb}$ fluxes and membrane potential in pancreatic B-cells. Biochem Pharmacol 31: 1407-1415

5. Meissner HP, Preissler M, Henquin JC (1980) Possible ionic mechanisms of the electrical activity induced by glucose and tolbutamide in pancreatic B cells. In: Waldhäusl WK (ed) Diabetes. Excerpta Medica, Amsterdam, pp 166-171

6. Hellman B (1981) Tolbutamide-stimulation of ${ }^{45} \mathrm{Ca}$ fluxes in microdissected pancreatic islets rich in B-cells. Molec Pharmacol 20: 83-88

7. Malaisse WJ, Hubinont C, Lebrun P, Herchuelz A, Couturier E, Deleers M, Malaisse-Lagae F, Sener A (1983) Mode of action of hypoglycemic sulfonylureas in the pancreatic $B$ cell: coinciding and conflicting views. In: Serrano-Rios M, Krall LP (eds) Clinical and pharmacological activities of sulfonylurea drugs. Excerpta Medica, Amsterdam pp 24-38

8. Hellman B, Sehlin J, Täljedal IB (1971) The pancreatic $\beta$ cell recognition of insulin secretagogues. II. Site of action of tolbutamide. Biochem Biophys Res Commun 45: 1384-1388

9. Hellman B (1974) Factors affecting the uptake of glibenclamide in microdissected pancreatic islets rich in $\beta$-cells. Pharmacology 11 : $257-267$

10. Hellman B, Täljedal IB (1979) Effects of sulfonylurea derivatives on pancreatic $\beta$ cells. In: Hasselblatt A, Bruchhausen FV (eds) Insulin II. Springer Verlag, Berlin Heidelberg New York, pp 175-194

11. Kaubisch N, Hammer R, Wollheim C, Renold AE, Offord RE (1982) Specific receptors for sulfonylureas in brain and in a $\beta$-cell tumor of the rat. Biochem Pharmacol 31: 1171-1174

12. Orci L, Ravazzola M, Amherdt M, Malaisse-Lagae F (1974) The $\beta$ cell boundary. In: Malaisse WJ, Pirart J (eds) Diabetes. Excerpta Medica, Amsterdam, pp 104-118

13. Deleers M, Malaisse WJ (1980) Ionophore-mediated calcium exchange diffusion in liposomes. Biochem Biophys Res Commun 95:650-657

14. Szoka F, Papahadjopoulos D (1978) Procedure for preparation of liposomes with large internal aqueous space and high capture by reverse-phase evaporation. Proc Natl Acad Sci USA 75: 4194-4198

15. Sehlin J (1973) Evidence for specific binding of tolbutamide to the plasma membrane of the pancreatic B cells. Acta Diabetol lat 5: 1052-1060

16. Täljedal IB (1974) Uptake of glibornuride by microdissected pancreatic islets. Hormone Res 5: 211-216

17. Hellman B, Sehlin J, Täljedal IB (1973) The pancreatic B cell recognition of insulin secretagogues. IV. Islet uptake of sulfonylurea. Diabetologia 9: 210-216

18. Malaisse WJ, Lebrun P, Herchuelz A (1982) Ionic determinants of bioelectrical activity in the pancreatic B-cell. Pflügers Arch 395: 201-203

19. Deleers M, Gelbcke M, Malaisse WJ (1983) Transport of $\operatorname{Pr}^{3+}$ by hypoglycemic sulfonylureas across liposomal membranes. FEBS Lett 151:269-279

20. Philips MC (1972) The physical state of phospholipids and cholesterol in monolayers, bilayers and membranes. Progr Surf Membrane Sci 5: 139-221

21. Singer SJ (1975) Architecture and topography of biologic membranes. In: Weissmann $\mathrm{G}$, Clairbone $\mathrm{R}$ (eds) Cell membranes; biochemistry, cell biology and pathology. HP Publishing, New York, pp 35-44
22. Montague W, Parkin EN (1980) Changes in membrane lipids of the $\beta$-cell during insulin secretion. In: Malaisse WJ, Täljedal IB (eds) Biochemistry and biophysics of the pancreatic B-cell. Horm Metab Res (Suppl) 10:153-157

23. Szoka F, Papahadjopoulos D (1980) Comparative properties and methods of preparation of lipid vesicles. Ann Rev Biophys Bioeng 9: 467--508

24. Deleers M, Malaisse WJ (1982) Binding of tumor-promoting and biologically inactive phorbol esters to artificial membranes. Cancer Lett 17: 135-140

25. Hellman B (1974) Potentiating effects of drugs on the binding of glibenclamide to pancreatic beta cells. Metabolism 23: 839-846

26. Malaisse WJ, Leclercq-Meyer V (1972) Insulinotropic action of a new sulphonylurea: gliclazide. Rev Europ Etud Clin Biol 17: 310-314

27. Herchuelz A, Malaisse WJ (1973) Insulinotropic potency of glipizide in vitro. Diabetologia 9: 309-310

28. Puls W, Keup U, Frerichs M (1974) Beeinflussung der Glykämie und Insulinämie unter Kohlenhydratbelastung durch Pro-Dia$\operatorname{ban}^{\circledR}$ an gesunden Versuchspersonen. In: Schöffling K, Kroneberg G, Laudahn G (eds) Pro-Diaban. F. K. Schattauer, Stuttgart, pp 99-106

29. Loubatieres A, Loubatieres-Mariani MM (1974) Experimental study of the betacytotropic and betacytotrophic action of glisoxepide (Pro-Diaban). In: Schöffling K, Kroneberg G, Laudahn G (eds) Pro-Diaban, F. K. Schattauer, Stuttgart, pp 53-63

30. Haupt E, Köberich W, Beyer J, Schöffling K (1971) Pharmacodynamic aspects of tolbutamide, glibenclamide, glibornuride and glisoxepide. $I$. Dose response relations and repeated administration in diabetic subjects. Diabetologia 7: 449 454

31. Haupt EK, Küllmer G, Schöffling K (1976) Pharmacodynamics of glurenorm. Diab Croatica 5: 373-391

32. Raptis S, Laube H, Katsilambros N, Hinz M, Rothmann G, Pfeiffer EF (1974) Tierexperimentelle und klinische Untersuchungen mit dem neuen Sulfonylharnstoff Glisoxepid (Pro-Diaban). In: Schöffling K, Kroneberg G, Laudahn G (eds) Pro-Diaban, F.K. Schattauer, Stuttgart, pp 73-82

33. Zilker T, Lüders L, Bottermann P (1975) Vergleichende Anwendung von Gliquidone und Tolbutamid nach intravenöser Gabe. Münch Med Wochenschr 117: 1421-1422

34. Zilker T, Waldthaler A, Ermler R, Bottermann P (1975) Wirkung von Gliquidon und Glibenclamid nach oraler Anwendung. Münch Med Wochenschr 117: 1423-1424

35. Balant L (1981) Clinical pharmacokinetics of sulphonylurea hypoglycaemic drugs. Clin Pharmacokin 6: 215-241

36. Bellens R (1961) Contribution à l'étude des mécanismes d'action des drogues hypoglycémiantes. Acta Endocrinol (Kbh) supplem 61

37. Malaisse W, Bellens R, Franckson JRM (1964) Comparaison de l'action de deux drogues hypoglycémiantes sur la glycémie et l'assimilation glucidique du chien normal. Arch Int Pharmacodyn Ther 149: 290-295

38. Schneider JA, Salgado ED, Jaeger D, Delahunt C (1959) The pharmacology of chlorpropamide. Ann NY Acad Sci 74: 427-441

Received: 15 March 1983

and in revised form: 24 June 1983

Professor W.J.Malaisse

Laboratory of Experimental Medicine

Brussels University Medical School

115, Boulevard de Waterloo

B-1000 Brussels, Belgium 